\title{
Descriptive Study of Eastern Hindi: A mixed language
}

\section{Ritesh Kumar}

Department of Linguistics

K.M. Institute of Hindi and Linguistics,

Dr. Bhim Rao Ambedkar University, Agra

riteshkrjnu@gmail.com

\section{Bornini Lahiri}

School of Language and Linguistics

Jadavpur University,

Kolkata

lahiri.bornini@gmail.com

\section{Deepak Alok}

\author{
Department of Linguistics \\ Rutgers, The State University of Newark, \\ USA
}

deepak06alok@gmail.com

\section{Abstract}

In this paper, we give a description of one of the varieties of Eastern Hindi spoken in the central, Magahi-speaking parts of Bihar (the variety spoken in and around the capital city of Patna) and present the case for it being a mixed language. Based on extensive empirical evidence, we conclude that Eastern Hindi is a conventionalised/plain mixed language (following the classification given in Bakkar (2000) and Matras and Bakker(2003)) which has come into being because of contact between the official Hindi and Magahi spoken in the region.

\section{Introduction}

Mixed languages are seen as the result of the merger of two or more recognizable source languages, particularly in the situation where community is bilingual (Meakins 2013; Bakker 1997). Thomason describes a mixed language as something in which the gRammar and the lexicon are taken directly from each source language in large chunks, usually without any significant compromises or indeed any other significant changes (Thomason 2001). The concept of Mixed language in contrast to code-switching, pidgin, creole or borrowing got attention in the area of contact linguistics by the work of Thomason and Kaufman (Thomason and Kaufman 1988). However, Bakker (1997) provided the first detailed account of a mixed language, Michif. Since then the idea of mixed languages has been discussed extensively in the literature. The mixed languages are broadly characterized into two types:

- GRammar-Lexicon mixed languages such as Ma'á (Mous 1994; Mous 2004), Bilingual Navajo (Schaengold 2004), Media Lengua (Muysken 1994) etc and

- Verb-Noun mixed languages such as Michif (Bakker 1997), Gurindji Kriol (McConvell and Meakins 2005), Light Warlpiri (O’Shannessy 2005) etc. (see Matras and Bakker (2003) for details).

Although both of these kinds of mixed languages look similar structurally, they emerge from very different social circumstances. Furthermore, they also show certain degree of typological variation in mixing of linguistic elements.

Mixed languages are distinguished from pidgin and creole languages in that they are not born out for communicative needs. Rather these are product of expression (Golovko 2003). In other words, it is argued that pidgin and creole languages came into existence for the need of communication among the people of two different communities whereas mixed languages are developed in the situation where a common language already exists and communication is not an issue among the people of that community (Meakins 2013) as we will see in the case of Eastern Hindi. In addition to this, mixed languages may also be formed by merger of more than two source languages, unlike pidgins and creoles.

The aim of this paper is not to get into the debate of mixed languages vis-a-vis codeswitching, pidgin or creole. Rather in this paper, we present the case for Eastern Hindi (the variety of Hindi spoken in and around the capital city of Patna, Jehanabad and Gaya) as a mixed language, assuming the concept of mixed languages.

In recent studies, linguists are interested in understanding the relationship between social forces and emergence of mixed languages. A common area of enquiry is to understand the extent to which social differences affect the structures of mixed languages. However, again our interest in this paper is to describe the characteristics of Eastern Hindi and suggest that it should be seen as a type of mixed language rather than how social forces played a role in the emergence the Eastern Hindi as a mixed language even though it must be emphasised here that the social factors have 
played a very crucial and significant role in the emergence of this language.

Eastern Hindi is mainly spoken in the state of Bihar and the eastern part of the state of Uttar Pradesh. Some of the other major languages spoken in these regions include Magahi, Maithili, Bhojpuri, Angika, Bajjika, etc. All of these language belong to the Eastern Indo-Aryan language family.

Census of India categorizes 49 so-called varieties of Hindi. Out of the 422 million people in this group, only $61 \%$ reported Hindi as their mother tongue. Bhojpuri and Magahi are among the top 5, with shares of $7.8 \%$ and $3.3 \%$, respectively. It is difficult to get the exact number of Eastern Hindi speakers as no such classification of Hindi has been made by the Government of India till now and the Census of India does not categories any language by this name. But in this paper we argue that Eastern Hindi is a different language (a mixed language) with unique features entirely different from standard Hindi.

The census does not mark any language as Eastern Hindi because speakers of this language do not identify their language as any different from that of the standard Hindi. So they take themselves as speakers of standard Hindi rather than that of Eastern Hindi. Moreover, the language is not the mother tongue of any community rather it is mainly used in the public domain so it is difficult to get the exact number of speakers of this language. But we can have a rough idea of number of speakers of this language. As per Census of India (2011), total population of Bihar is $103,804,637$. Out of this, $70.12 \%$ responded as Hindi speakers. But as per our research it is hard to find so called standard Hindi in this region which means that these speakers are referring to the Eastern Hindi spoken in the region. Following table shows the percent of speakers of some of the major languages in Bihar (Census 2011).

\begin{tabular}{|l|l|l|}
\hline \multicolumn{1}{|c|}{ Language } & \multicolumn{1}{|c|}{ Language family } & \multicolumn{1}{c|}{ Speakers (\%) } \\
\hline Hindi [Eastern Hindi] & Indo-Aryan & $\mathbf{7 0 . 1 2 \%}$ \\
\hline Bhojpuri & Indo-Aryan & $14 \%$ \\
\hline Magahi & Indo-Aryan & $12 \%$ \\
\hline Maithili & Indo-Aryan & $73.27 \%$ \\
\hline Urdu & Indo-Aryan & $16.91 \%$ \\
\hline Bengali & Indo-Aryan & $0.53 \%$ \\
\hline Santali & Austroasiatic & $0.47 \%$ \\
\hline
\end{tabular}

Table 1: Distribution of speakers of different languages in Bihar

In the context of Bihar, the respective language of each community is acquired as a mother tongue/first language by almost all the members of the community. On the other hand, official Hindi 
is learned mainly through education and other means of contact such as TV, movies, radio, newspapers etc. Furthermore with the adaptation of this official Hindi as the official language of the nation as well as the state of Bihar, the Eastern Indo-Aryan languages began to come in contact with the official Hindi through official documents, education system and written literature. This, coupled with a negative language attitude towards the Bihari languages (which are perceived as the dialects of Hindi mainly because of a very high lexical similarity among the languages), heavily prompted the speakers of these Bihari languages to switch over to the official Hindi. Consequently we have varieties of Eastern Hindi ${ }^{1}$ which can be termed as Magahi variety of Eastern Hindi, Maithili variety of Eastern Hindi, Bhojpuri variety of Eastern Hindi and so on.

Since Eastern Hindi consists of a large lexicon from the Bihari languages and they also share their Noun Phrase and parts of Verb Phrase, too, with the Bihari languages, we propose to keep it under the Bihari sub-group of Eastern sub-branch of New Indo-Aryan languages ${ }^{2}$ (see the tree below)

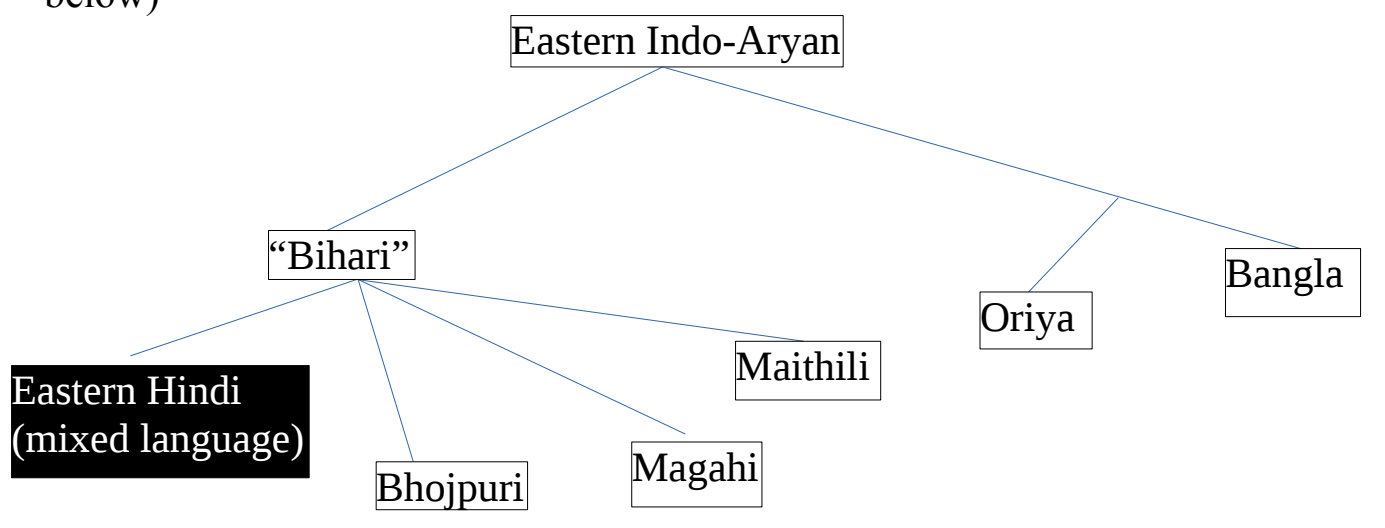

Fig 1: Proposed Genealogical Position of the "mixed" Eastern Hindi

In this paper we will give a description of this mixed language, concentrating mainly on the Magahi variety, spoken in and around the capital city of Patna.

\section{The linguistic structure}

The source languages of Eastern Hindi are one of the Eastern Indo-Aryan languages (here, Magahi) and the official Hindi. It has become the lingua franca not only among urban speakers of Eastern Indo-Aryan languages today but also in small markets, fairs, villages, etc. Many urban household use this language as their mother tongue. As a result Eastern Hindi shares lexical, morphological, phonological and syntactic features with both the Eastern Indo-Aryan languages and the official Hindi. As we have mentioned above, from now on we will concentrate mainly on the contact between Magahi and official Hindi and for the present purposes, Eastern Hindi will refer mainly to the Hindi spoken by the people living in Maghai-speaking areas.

\section{Lexicon of Eastern Hindi}

Like most of the Eastern Indo-Aryan languages, Magahi and official Hindi share a large number of lexicon (although there is no systematic study on it), which also contributes to the spread of the view that it is the dialect of Hindi. And so consequently Eastern Hindi also shares a large number of lexicons with the official Hindi. However it also has a large number of lexical items borrowed from Magahi, particularly in cases where official Hindi does not have a parallel lexical item. In cases where Magahi uses a different lexical item from the official Hindi, the speakers optionally use both the words (but predominantly it is taken from Magahi). Besides the content

1 It must be noted here that this 'Eastern Hindi' that we propose here is very different from the 'Eastern Hindi' group of languages / language that was proposed by Grierson and others. We have used the same name for the lack of a better name. An alternative to this was 'Bihari Hindi' which again has been used in a different sense in the previous literature. So we may continue using this name for the lack of an alternatives name.

2 We propose this classification based on a preliminary investigation and it needs to be investigated further for a better understanding of the exact genealogical position of this new mixed language. 
words, a substantial number of function words used in Eastern Hindi are also taken from Magahi. These include Wh-words, postpositions, pronouns, conjunctions, quantifiers etc. Some of the examples are listed below

\begin{tabular}{|c|c|c|c|}
\hline Magahi & Hindi & English & Eastern Hindi \\
\hline (kəpra) $\mathrm{p}^{\mathrm{h}}$ icna (v.) & (kəpra) $\mathrm{d}^{\mathrm{h}}$ ona & $\begin{array}{l}\text { To wash clothes (Magahi) } \\
\text { To wash something (Hindi) }\end{array}$ & (kəpra) $p^{\text {hicna }}$ \\
\hline mətijana (v.) & -- & To ignore & mətijana \\
\hline burbək (n.) & bewзkuf & idiot & burbək/bewзkuf/bekuf \\
\hline askəț (n.) & aləsjə & laziness & askət \\
\hline $\mathrm{d}^{\mathrm{h}} \mathrm{i}: \mathrm{t}^{\mathrm{h}}$ (adj.) & -- & $\begin{array}{l}\text { Someone who does not listen } \\
\text { to anybody }\end{array}$ & $\mathrm{d}^{\mathrm{h}} \mathrm{i}: \mathrm{t}^{\mathrm{h}}$ \\
\hline $\mathrm{t}^{\mathrm{h}} \mathrm{et}^{\mathrm{h}} \partial \mathrm{r}(\mathrm{adj})$. & -- & $\begin{array}{l}\text { Someone who is unaffected } \\
\text { by anything }\end{array}$ & $\mathrm{t}^{\mathrm{h}} \mathrm{et}^{\mathrm{h}} \partial \mathrm{r}$ \\
\hline ka/kəuci (wh-word) & kja & what & $\mathrm{ka} / \mathrm{kəuci}$ \\
\hline ləgi/la (pp.) & ke lije & for & ləgi/la \\
\hline həm (pron.) & $\mathrm{m} \tilde{\varepsilon}$ & I & həm \\
\hline
\end{tabular}

\section{Morphology of Eastern Hindi}

Eastern Hindi also shares morphological elements with both of its source languages. We discuss this in detail in the following sub sections.

\section{Noun Morphology in Eastern Hindi}

Noun morphology of Eastern Hindi is taken entirely from Magahi. The nouns are not marked for ergativity (examples 1, 2, 4 below) and oblique case (example 1 below) unlike official Hindi. Along with this, nouns may take -wa as suffix for marking familiarity (Alok 2012). Furthermore Eastern Hindi is a classifier language, unlike official Hindi, which is a noun class language. Thus in Eastern Hindi, there is no distinction between two noun classes that Hindi have. In popular parlance and much of linguistic literature the two classes of Hindi are termed two genders of the language and as is the general feature of noun class languages, every noun has to be in one of the classes (see Aikhenvald $(2000,2006)$ 2006) for details). Thus Eastern Hindi does not exhibit any gender-based agreement system within the noun phrase, except the cases where natural gender of the referent is available (examples 4 and 5 below). Also as is the case with most of the classifier languages, Eastern Hindi does not exhibit number agreement (examples 1, 2 and 3 below). It has some pragmatic consequences also. For example, generic reading in official Hindi is given by the bare plurals but in Eastern Hindi bare singular is ambiguous for both generic as well as specific reading (example 5 below). Let us take a look at the following examples which exhibit these features of Eastern Hindi.

\begin{tabular}{|c|c|c|c|c|c|c|}
\hline ram & $\mathrm{ka}$ & bet-wa/beta & du-ie-go & roti & $\mathrm{k}^{\mathrm{h}} \mathrm{aja}$ & (Eastern Hindi) \\
\hline Ram & POSS & son & two-EMP-CLA & roti & eat-PST & \\
\hline ram & ke & bet-wa & du-ie-go & roti & $\mathrm{k}^{\mathrm{h}}$ əilkəi & (Magahi) \\
\hline
\end{tabular}




\begin{tabular}{lllllll} 
Ram & POSS & son & two-EMP-CLA & roti & eat-PST \\
ram & ke & bete-ne & do hi & rotija & $\mathrm{k}^{\mathrm{h}} \mathrm{aj} \tilde{1}$ & (Western Hindi) \\
Ram & POSS & son-OBL-ERG & two EMP & roti-PL & eat-PL-PST \\
\multicolumn{5}{c}{ Ram's son ate only two rotis. }
\end{tabular}

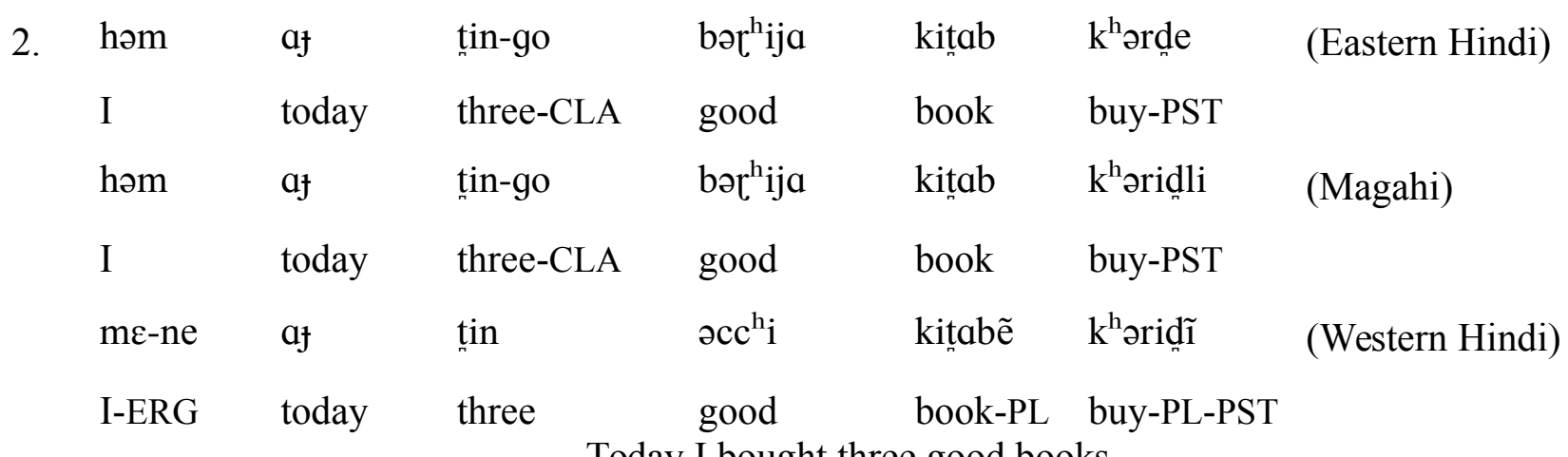

Today I bought three good books.

3. af ke miting-wa me bəri-məni admi aja hua $\stackrel{n}{\mathrm{th}}^{\mathrm{a}}$ (Eastern Hindi) today POSS meeting-FAM LOC many-CLA people come ECV AUX af ke miting-wa me bəri-məni admi ajel həlt ${ }^{\mathrm{h}}$ in (Magahi) today POSS meeting-FAM LOC many-CLA people come ECV-PST af ke miting me bəhut admi aje hue $\underline{n}^{\mathrm{h}} \mathrm{e}$ (Western Hindi) today POSS meeting LOC many people come-PL ECV-PL AUX-PL Lot of people had come in today's meeting.

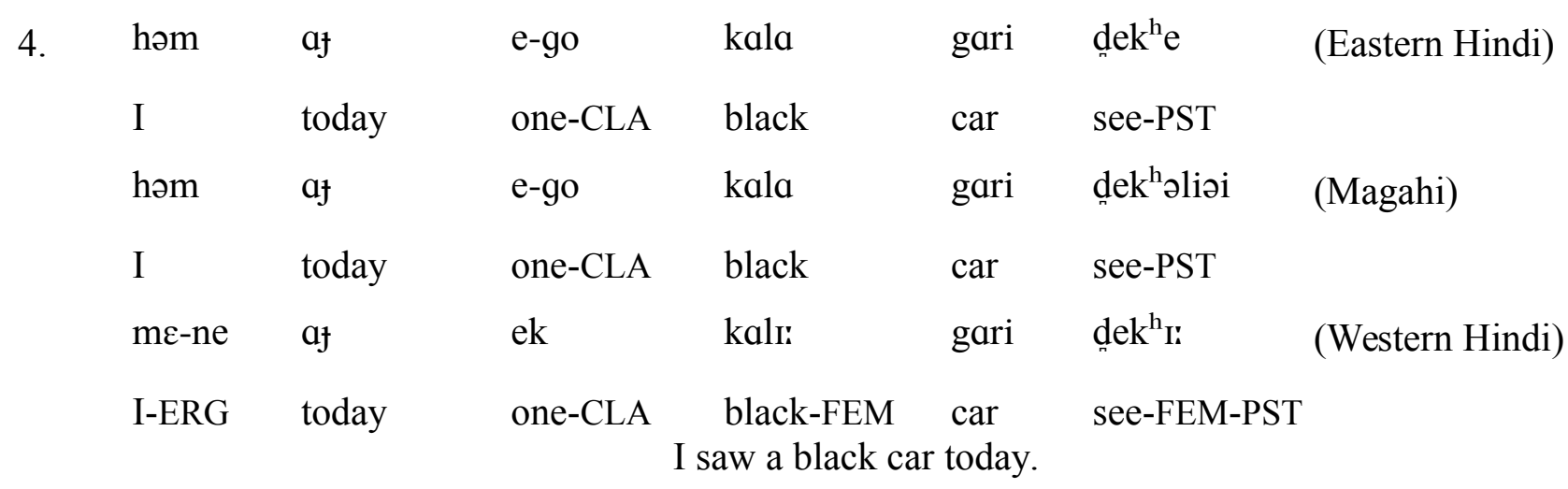

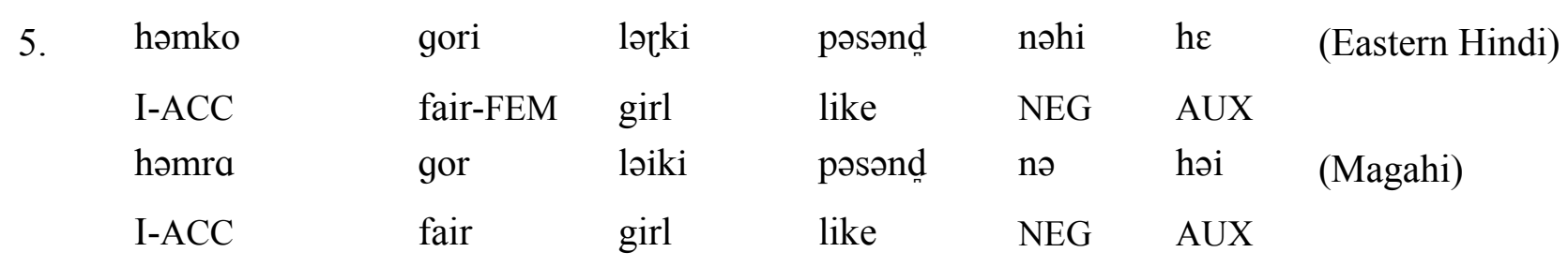




$\begin{array}{lllllll}\operatorname{muj}^{\mathrm{h}} \mathrm{e} & \text { gori } & \text { lərkijã } & \text { pəsənd } & \text { nəhi } & \text { hẽ } & \text { (Western Hindi) } \\ \text { I-ACC } & \text { fair-FEM } & \text { girl-PL } & \text { like } & \text { NEG } & \text { PL-AUX }\end{array}$

I do not like fair girls.

As a result of these features the pronominal paradigm of Eastern Hindi is also distinct from official Hindi. Since there is no oblique and number marking, Eastern Hindi does not have a distinct pronominal form for these features. Thus there is a two-way distinction between person and honorificity in the pronominal forms. The plural is marked by attaching a suffix -log with any of the pronominal forms (example 5 above). The pronominal paradigm is given in the Table 1 below

\begin{tabular}{|c|c|c|}
\hline & +Hon & -Hon \\
\hline First Person & həm & həm \\
\hline Second Person & tum & ap \\
\hline Third Person & wo & we \\
\hline
\end{tabular}

Table1: Pronominal Paradigm in Eastern Hindi

\section{Verb Morphology in Eastern Hindi}

Verb morphology of Eastern Hindi is predominantly taken from Western Hindi. Even though there is no noun-verb agreement in terms of gender (except in terms of natural gender agreement) and number, the TAM markers in Eastern Hindi is taken almost entirely from Hindi. Besides the examples given above, the following examples will illustrate this point more clearly.

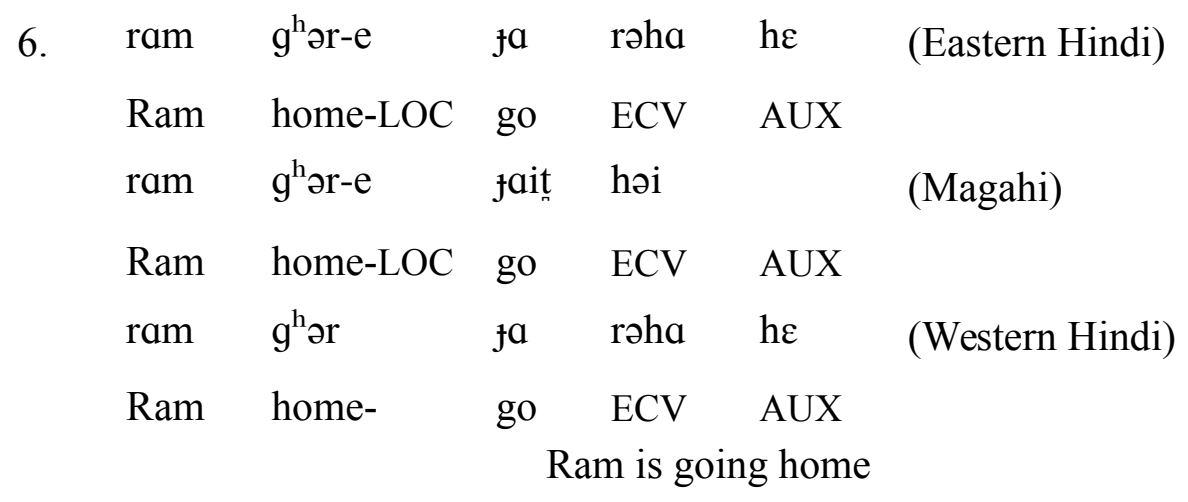

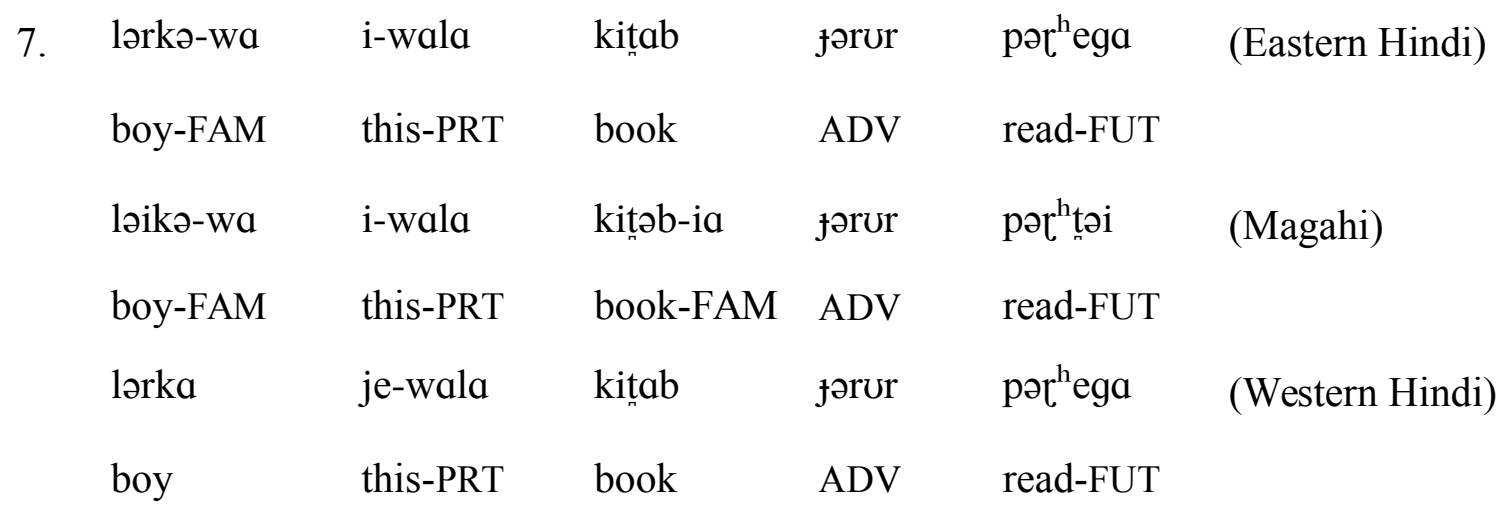

The boy will definitely read this book 


\begin{tabular}{|c|c|c|c|c|}
\hline \multirow{3}{*}{$\begin{array}{l}\text { 8. } \quad \text { ram } \\
\text { Ram }\end{array}$} & am & $\mathrm{k}^{\mathrm{h}} \mathrm{ata}$ & $\mathrm{t}^{\mathrm{h}} \mathrm{a}$ & \multirow[t]{2}{*}{ (Eastern Hindi) } \\
\hline & mango & eat & AUX-PST & \\
\hline & $\mathrm{am}$ & $\mathrm{k}^{\mathrm{h}} \mathrm{a}$ & hələi & \multirow[t]{2}{*}{ (Magahi) } \\
\hline \multirow{3}{*}{8.} & mango & eat & AUX-PST & \\
\hline & $\mathrm{am}$ & $\mathrm{k}^{\mathrm{h}} \mathrm{atra}$ & $\mathrm{t}^{\mathrm{h}} \mathrm{a}$ & \multirow[t]{2}{*}{ (Western Hindi) } \\
\hline & mango & eat & AUX-PST & \\
\hline
\end{tabular}

However it must be mentioned here that there are some exceptional cases in verbal morphology where the verbs in Eastern Hindi takes the tense marker from Magahi but even in these cases it is compulsory to either take the auxiliary or explicator compound verb from Hindi. We have identified three patterns where the verbs in Eastern Hindi could take the tense marker of Magahi (it must be kept in mind that these markers are optional in Eastern Hindi and the official Hindi counterpart could also be used). These three patterns and a description for each of them is given below:

- Pattern 1: V(Perfective) + Aux (with the past tense marker of Magahi). It is a construction parallel to the Western Hindi construction of 'V(Perfective) + hua + Aux' and Magahi construction of 'V(Perfective) + Aux', with the 'Aux' always being that of official Hindi with an optional choice between 'V(Perfective)' from Magahi or 'V(Perfective) + hua' from Western Hindi. The following examples illustrate the parallel constructions in Eastern Hindi, Magahi and Western Hindi representing this pattern.

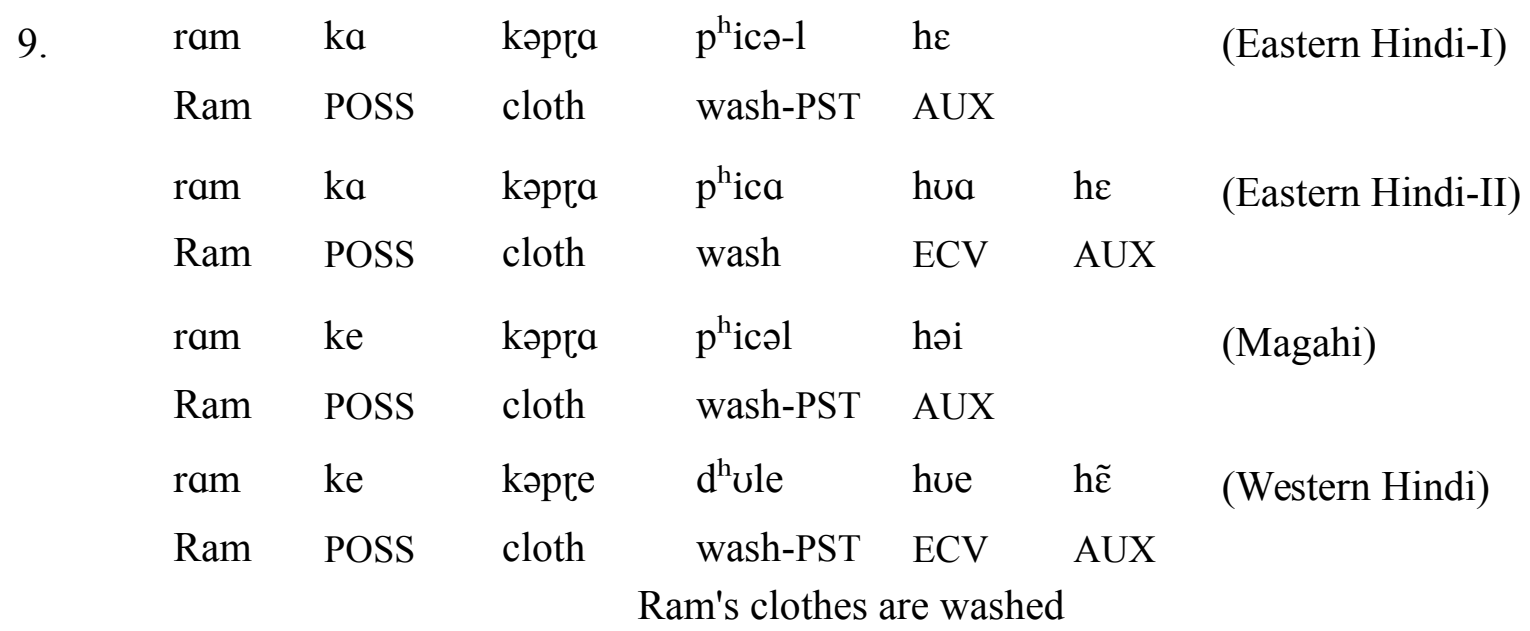

- $\quad$ Pattern 2: V(Perfective) + fa roha + Aux (with the past tense marker of Magahi). It is a construction parallel to a similar official Hindi and Magahi construction of $\mathrm{V}($ Perfective $)+\mathrm{fa}^{\mathrm{a}}$ rəhləi + Aux. The following example illustrates this pattern.

\begin{tabular}{|c|c|c|c|c|c|c|c|}
\hline həmse & $\partial b$ & cələ-1 & nəhi & fa & rəha & he & (Eastern Hindi-I) \\
\hline I-DAT & now & walk-ABL-PST & NEG & $\mathrm{ECV}$ & $\mathrm{ECV}$ & AUX & \\
\hline həmse & ob & cəla & nəhi & $\mathrm{fa}$ & rəha & $\mathrm{h} \varepsilon$ & (Eastern Hindi-II) \\
\hline I-DAT & now & walk-ABL & NEG & $\mathrm{ECV}$ & $\mathrm{ECV}$ & AUX & \\
\hline
\end{tabular}




$\begin{array}{llllllll}\text { həmra se } & \text { əb } & \text { cələ-1 } & \text { nə } & \text { fait } & \text { həi } & & \text { (Magahi) } \\ \text { I-DAT } & \text { now } & \text { walk-ABL-PST } & \text { NEG } & \text { ECV } & \text { ECV } & \text { AUX } & \\ \text { muj }^{\text {h}} \text { se } & \text { əb } & \text { cəla } & \text { nəhi } & \text { fa } & \text { rəha } & \text { he } & \text { (Western Hindi) } \\ \text { I-DAT } & \text { now } & \text { walk-ABL } & \text { NEG } & \text { ECV } & \text { ECV } & \text { AUX } & \end{array}$

I cannot walk any more

- $\quad$ Pattern 3: V(Future) + kərenge (with the future tense marker of Magahi). It is a construction parallel to the official Hindi construction of $\mathrm{V}($ Future $)+$ hi and Magahi construction of V(Future $)+$ kərbəu. Since the particle 'hi' is not used in Eastern Hindi, this construction does not have an optional counterpart as in the previous two patterns. The following example illustrates this pattern in Eastern Hindi.

\begin{tabular}{|c|c|c|c|c|c|}
\hline 11. & həm & potna & $j \varepsilon-b-e$ & kəreyge & (Eastern Hindi) \\
\hline today & I & patna & go-FUT-EMP & ECV & \\
\hline$a_{\mathfrak{f}}$ & həm & potna & $\jmath \varepsilon-b-e$ & kərbəi & (Magahi) \\
\hline today & I & patna & go-FUT-EMP & ECV & \\
\hline$a_{f}$ & həm & potna & fajenge & hi & (Western Hindi) \\
\hline today & I & patna & go-FUT & EMP & \\
\hline
\end{tabular}

Today I will definitely go to Patna

\section{Classifiers in Eastern Hindi}

Since Eastern Hindi does not have number morphology, it cannot be combined with numeral without an intervening element. Thus the nominal cannot function as a complement to a numeral in Eastern Hindi, it must instead be first combined either with the classifier go or $t^{\mathrm{h}} \mathrm{O}$ (the two elements are in free variation). This feature of Eastern Hindi is taken from Magahi. The following examples (12)-(13) illustrate this:

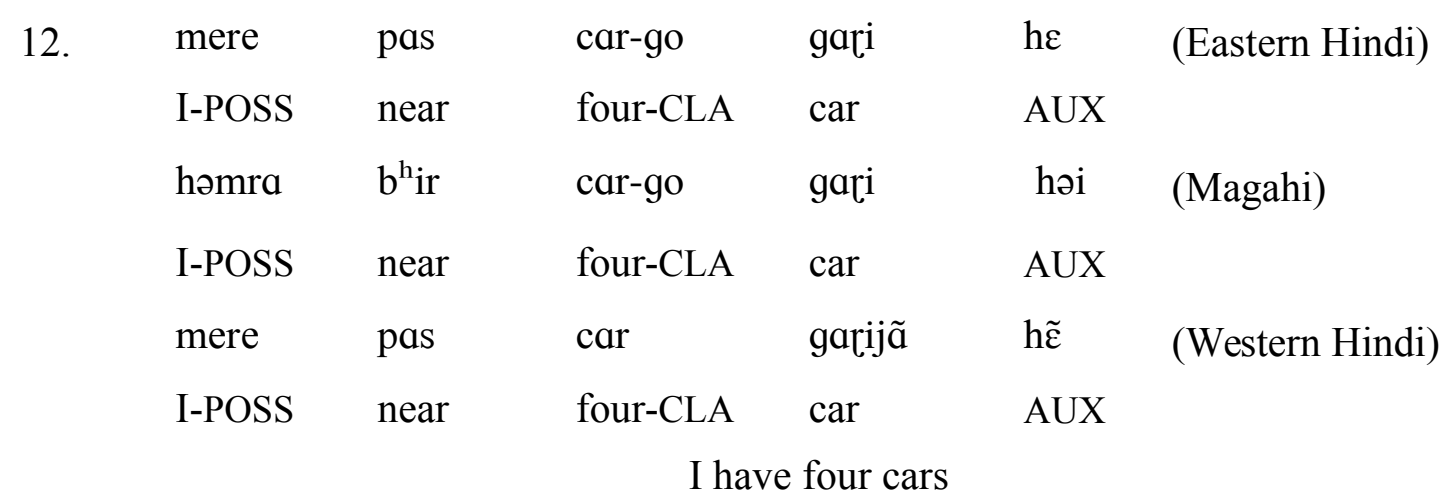

$\begin{array}{lllllllll}\text { 13. bihar } & \text { ke } & \text { pãc-go } & \text { bera } & \text { səhər } & \text { ke } & \text { nam } & \text { bətaije } & \text { (Eastern Hindi) } \\ \text { Bihar } & \text { POSS } & \text { five-CLA } & \text { big } & \text { city } & \text { POSS } & \text { name } & \text { tell-HON } & \end{array}$




$\begin{array}{lllllllll}\text { bihar } & \text { ke } & \text { pãc-go } & \text { bera } & \text { səhər } & \text { ke } & \text { nam } & \text { bətabə } & \text { (Magahi) } \\ \text { Bihar } & \text { POSS } & \text { five-CLA } & \text { big } & \text { city } & \text { POSS } & \text { name } & \text { tell-HON } & \\ \text { bihar } & \text { ke } & \text { pãc } & \text { bere } & \text { Səhərõ } & \text { ke } & \text { nam } & \text { bətaije } & \text { (Western Hindi) } \\ \text { Bihar } & \text { POSS } & \text { five-CLA } & \text { big } & \text { city } & \text { POSS } & \text { name } & \text { tell-HON } & \end{array}$

Tell me the name of five big cities of Bihar

\section{Agreement in Eastern Hindi}

The agreement system of Eastern Hindi is like Magahi even at the level of clause. The Verb agrees with Noun only in person and honorificity. However it does not show the addressee agreement as Magahi does. Some of the examples given above (examples 1, 2, 3,4) illustrate this.

\section{Particles in Eastern Hindi}

Emphatic expression is shown by the particle hI: in Hindi whereas by the inflection marker -e/-ie in Magahi. Eastern Hindi follows Magahi in marking this particle as shown in examples 1, 11, 14.

14.

$\begin{array}{llll}\text { ram-e } & \text { fayega. } & & \begin{array}{l}\text { (Eastern } \\ \text { Hindi) }\end{array} \\ \text { Ram-EMP } & \text { go-FUT } & & \\ \text { ram-e } & \text { feto } & & \text { (Magahi) } \\ \text { Ram-EMP } & \text { go-FUT } & & \\ \text { ram } & \text { hI: } & \text { fajega. } & \text { (Hindi) } \\ \text { Ram } & \text { EMP } & \text { go-FUT } & \\ \text { Only Ram shall go } & & \end{array}$

\section{Summing Up}

In this paper we have given a description of some of the morphological and syntactic features of Eastern Hindi. It is quite evident that the language has noun phrase from one language (Magahi/Bhojpuri/other Bihari languages) and verb phrase from another (Hindi). It is closest to the case of Mednyj Aleut (formed out of interaction between Russian and Aleyut arising out of marriages in between the two communities) spoken in Mednyj Island in the Bering Strait until recently. In this language Aleut provides majority of the lexicon, nominal inflections and derivational suffixes while Russian provides finite verbal inflectional morhology (Golovko and Vakhtin 1990; Sekerina 1994; Thomason 1997). The case of Eastern Hindi is very similar to this language where verbal morphology is largely from Hindi while lexicon, nominal morphology, agreement system and phonology is largely from Magahi. Thus it could be concluded that Eastern Hindi is a conventionalised/plain mixed language with a VP-NP distinction (based on the classification given in (Bakker 2000) and (Matras and Bakker 2003)) which has come into being because of contact between Hindi and Maghi. There are also different varieties of Eastern Hindi depending on which language is involved in the contact. These needs to be investigated further for a fuller analysis of this language. A more detailed phonological analysis as well as structural analysis of the language is also needed. 


\section{Glossary of Abbreviations:}

$\begin{array}{ll}\text { ABL } & \text { Ability Marker } \\ \text { ACC } & \text { Accusative Case } \\ \text { ADV } & \text { Adverb } \\ \text { AUX } & \text { Auxilliary/Copula } \\ \text { CLA } & \text { Classifier } \\ \text { DAT } & \text { Dative Case } \\ \text { ECV } & \text { Explicator Compound Verb/Serial Verb } \\ \text { EMP } & \text { Emphatic Marker/Focus } \\ \text { ERG } & \text { Ergative Case } \\ \text { FAM } & \text { Familiarity Marker } \\ \text { FEM } & \text { Feminine Gender } \\ \text { FUT } & \text { Furture Tense } \\ \text { HON } & \text { Honorific } \\ \text { LOC } & \text { Locative Case } \\ \text { NEG } & \text { Negation Particle } \\ \text { OBL } & \text { Oblique Case } \\ \text { PL } & \text { Plural Marker } \\ \text { POSS } & \text { Possession Marker/Genitive Case } \\ \text { PRT } & \text { Particle } \\ \text { PST } & \text { Past Tense }\end{array}$




\section{References}

Aikhenvald, Alexandra Y. 2006. "Classifiers and Noun Classes: Semantics." Encyclopedia of Language and Linguistics. Elsevier Ltd.

Aikhenvald, Alexandra.Y. 2000. A Typology of Noun Categorization Devices. Oxford: Oxford University Press.

Alok, Deepak. 2012. “A Language Without Article: The Case of Magahi”. Jawaharlal Nehru University.

Bakker, Peter. 1997. A Language of Our Own: The Genesis of Michif, the Mixed Cree-French Language of the Canadian Metis. Oxf: Oxford University Press.

. 2000. "Convergence Intertwining : An Alternative Way Towards The Genesis Of Mixed Languages." Languages in Contact 28: 29-35. http://www.jstor.org/stable/40997149.

Golovko, Evgeniy. 2003. 'Language Contact and Group Identity: The Role of 'Folk' Linguistic Engineering." In The Mixed Language Debate: Theoretical and Empirical Advances, ed. Yaron Matras and Peter Bakker, 177-208. Berlin: Mouton de Gruyter.

Golovko, Evgeniy, and Nikolai Vakhtin. 1990. “Aleut in Contact: The CIA Enigma.” Acta Linguistica Hafniensia 72: 97-125.

Matras, Yaron, and Peter Bakker. 2003. The Mixed Language Debate: Theoretical and Empirical Advances. Berlin: Walter de Gruyter.

McConvell, Patrick, and Felicity Meakins. 2005. "Gurindji Kriol: A Mixed Language Emerges from Code-switching." Australian Journal of Linguistics 25 (1): 9-30.

Meakins, Felicity. 2013. “Mixed Languages.” In , ed. Y. Matras and P. Bakker. Berlin: Mouton de Gruyter.

Mous, Maarten. 1994. “Ma'á or Mbugu.” In Mixed Languages: 15 Case Studies in Language Intertwining, ed. Peter Bakker and Maarten Mous, 175-200. Amsterdam: Uitgave IFOTT.

- 2004. The Making of a Mixed Language: The Case of Ma'a/Mbugu. Amsterdam/Philadelphia: John Benjamins Publishing Company.

Muysken, Pieter. 1994. “Media Lengua.” In Mixed Languages: 15 Case Studies in Language Intertwining, ed. Peter Bakker and Maarten Mous, 201-205. Amsterdam: Uitgave IFOTT.

O’Shannessy, Carmel. 2005. “Light Warlpiri: A New Language.” Australian Journal of Linguistics 25 (1): 31-57.

Schaengold, Charlotte C. 2004. "Bilingual Navajo: Mixed Codes, Bilingualism, And Language Maintenance". The Ohio State University.

Sekerina, I. A. 1994. “Copper Island Aleut: A Mixed Language.” The Languages of the World 8 (1): $14-31$.

Thomason, Sarah G., ed. 1997. Contact Languages: A Wider Perspective. Amsterdam: John Benjamins Publishing Company.

Thomason, Sarah G. 2001. Language Contact An Introduction. Edinburgh: Edinburgh University Press.

Thomason, Sarah G., and Terrence Kaufman. 1988. Language Contact, Creolization, and Genetic Linguistics. Berkeley/Los Angeles: University of California Press. 